\title{
Clofarabine and high-dose cytosine arabinoside in the treatment of refractory or relapsed acute myeloid leukaemia
}

\author{
Eric Tse • Anskar Y. H. Leung • Joycelyn Sim • \\ Harold K. K. Lee • Herman S. Y. Liu • Sze-Fai Yip • \\ Yok-Lam Kwong
}

Received: 5 March 2011 /Accepted: 21 March 2011 /Published online: 1 April 2011

(C) The Author(s) 2011. This article is published with open access at Springerlink.com

\begin{abstract}
Clofarabine $\left(40 \mathrm{mg} / \mathrm{m}^{2} /\right.$ day $\left.\times 5\right)$ and high-dose cytosine arabinoside (Ara-C, $1-2 \mathrm{~g} / \mathrm{m}^{2} /$ day $\times 5$ ) were used in 10 men and 11 women, at a median age of 45 (22-62) years, with refractory $(N=4)$ and relapsed $(N=17)$ acute myeloid leukaemia, after a median of $3(2-5)$ prior regimens. Grade 4 myelosuppression was observed in all cases, with two patients dying of bacterial sepsis. Nine patients achieved a complete remission. Disease status, number of prior therapies, and cytogenetic aberrations were not associated with the outcome. However, remission was only achieved with Ara-C at $2 \mathrm{~g} / \mathrm{m}^{2} /$ day and not $1 \mathrm{~g} / \mathrm{m}^{2} /$ day ( $9 / 15$ versus $0 / 4, P=0.03)$.
\end{abstract}

Keywords Clofarabine $\cdot$ Cytosine arabinoside $\cdot$ Refractory . Relapse $\cdot$ Acute myeloid leukaemia

Eric Tse and Anskar Y. H. Leung contributed equally to this work.

E. Tse · A. Y. H. Leung $\cdot$ Y.-L. Kwong $(\bowtie)$

Department of Medicine, Queen Mary Hospital,

Pokfulam Road,

Hong Kong, China

e-mail: ylkwong@hkucc.hku.hk

J. Sim $\cdot$ H. K. K. Lee

Department of Medicine, Princess Margaret Hospital,

Hong Kong, China

H. S. Y. Liu

Department of Medicine,

Pamela Youde Nethersole Eastern Hospital,

Hong Kong, China

S.-F. Yip

Department of Medicine, Tuen Mun Hospital,

Hong Kong, China

\section{Introduction}

Acute myeloid leukaemia (AML) is an aggressive haematological malignancy affecting mainly adults. The use of combination chemotherapy is effective and curative in some patients. The standard induction chemotherapy is a combination of an anthracycline and standard-dose cytosine arabinoside (Ara-C, $100-200 \mathrm{mg} / \mathrm{m}^{2} /$ day), which results in a complete remission (CR) rate of $60-70 \%$. Consolidation or post-remission chemotherapy, with or without haematopoietic stem cell transplantation (HSCT), further improves the outcome by decreasing relapses.

However, in primary refractory or relapsed AML, the prognosis is generally unfavourable, with salvage chemotherapy giving a remission rate of merely $10-40 \%$. Factors predicting a poor outcome include advanced age, adverse cytogenetic or molecular findings and a short duration of prior remission in relapsed cases [1].

High-dose Ara-C (1-6 g/m²/day) alone or in combination with other drugs is often employed as a salvage strategy for AML. An intriguing concept in the use of highdose Ara-C involves the pre-administration of the purine analogue fludarabine. In the FLAG regimen (fludarabine, high-dose Ara-C), fludarabine is first administered, which activates deoxycytidine kinase, thus enhancing the intracellular conversion of other purine analogues to their active metabolites. Thereafter, when Ara-C is administered, a higher intracellular concentration of its active metabolite Ara-CTP is attained, providing a putative mechanism of "biochemical modulation" whereby cell killing is increased [2]. Variations of the FLAG regimen, including FLAG-IDA (idarubicin), result in a remission rate of $30-50 \%$ in relapsed and refractory AML [3, 4]. 
Clofarabine (2-chloro-2'-fluoro-deoxy-9- $\beta$-D-arabinofuranosyladenosine) is a purine analogue designed to combine the favourable properties of fludarabine and 2chlorodeoxyadenosine [5]. Clofarabine alone or in combination chemotherapy has been shown to be effective in induction therapy of adult AML, especially in the elderly population [6-8]. In relapsed or refractory AML, clofarabine had also shown activity [9]. Because of the structural similarity between purine analogues, a putative synergism between clofarabine and Ara-C, similar to that between fludarabine and Ara-C, has been postulated $[10,11]$.

In this study, we examined the efficacy and safety of sequential clofarabine and high-dose Ara-C in relapsed and refractory AML.

\section{Materials and methods}

Patients Consecutive adult patients $(\geq 18$ years old $)$ with primary refractory (failure of $\geq 2$ induction regimens) or relapsed AML presenting between January 2009 and August 2010, who had adequate renal and liver functions (serum creatinine $<2 \times$, bilirubin $<1.5 \times$, and alanine aminotransferase and aspirate aminotransferase $<10 \times$ upper limits of the reference range) and no active infection, were studied. Patients gave informed consent. Cytogenetic abnormalities were categorized according to the revised Medical Research Council prognostic classification [12].

Treatment The treatment comprised clofarabine $\left(40 \mathrm{mg} / \mathrm{m}^{2} /\right.$ day, 1-h intravenous infusion) (Clofarabine Humanitarian Program, Genzyme Corporation, Cambridge, MA, USA) and Ara-C (1-2 g/ $\mathrm{m}^{2} /$ day, 2-h intravenous infusion starting $4 \mathrm{~h}$ after clofarabine infusion), given for 5 days. Patients who achieved CR received further consolidation chemotherapy with clofarabine + Ara-C at the same dose and schedule for a planned two courses, high-dose Ara-C ( $3 \mathrm{~g} / \mathrm{m}^{2}$ every $12 \mathrm{~h}$ for four doses) or allogeneic HSCT. Adverse effects were graded according to the World Health Organization criteria. Standard criteria for response were adopted.

Statistical analyses Univariate analyses were performed for the association between response to therapy and disease status (refractory versus relapsed), age ( $\leq$ versus $>50$ years), number of prior therapies $(\leq$ versus $>2)$, and cytogenetic alterations (adverse versus others).

Table 1 Demographical and clinicopathological features of 21 AML patients receiving clofarabine and high-dose cytosine arabinoside

\begin{tabular}{|c|c|c|c|c|c|c|}
\hline Number & Gender & Age & Remission duration & Prior treatment (number) & Cytogenetics & FLT3 ITD \\
\hline \multicolumn{7}{|c|}{ Primary refractory } \\
\hline \multirow[t]{3}{*}{4} & $\mathrm{M}=2$ & 49 (34-61)years & N.A. & $3+7(N=4)$ & Favourable $(N=0)$ & Positive $(N=0)$ \\
\hline & $\mathrm{F}=2$ & & & $\operatorname{ICE}(N=3)$ & Intermediate $(N=2)$ & Negative $(N=4)$ \\
\hline & & & & $\begin{array}{l}\text { MTZ + MAra-C }(N=3) \\
\text { FLAG }(N=1)\end{array}$ & Adverse $(N=2)$ & \\
\hline \multicolumn{7}{|c|}{ First relapse } \\
\hline \multirow[t]{5}{*}{11} & $\mathrm{M}=4$ & $45(22-62)$ years & $5(2-12)$ months & $3: 7(N=11)$ & Favourable $(N=1)$ & Positive $(N=1)$ \\
\hline & $\mathrm{F}=7$ & & & HDAra-C $(N=5)$ & Intermediate $(N=7)$ & Negative $(N=7)$ \\
\hline & & & & $\operatorname{ICE}(N=8)$ & Adverse $(N=3)$ & Not available $(N=3)$ \\
\hline & & & & $\begin{array}{l}\text { MTZ + MAra-C }(N=3) \\
\text { FLAG }(N=2)\end{array}$ & & \\
\hline & & & & Allogeneic HSCT $(N=2)$ & & \\
\hline \multicolumn{7}{|c|}{ Second relapse } \\
\hline \multirow[t]{4}{*}{6} & $\mathrm{M}=4$ & $44(22-59)$ years & $4.5(2-12)$ months & $3: 7(N=6)$ & Favourable $(N=0)$ & Positive $(N=1)$ \\
\hline & $\mathrm{F}=2$ & & & HDAra-C $(N=3)$ & Intermediate $(N=4)$ & Negative $(N=4)$ \\
\hline & & & & $\operatorname{ICE}(N=6)$ & Adverse $(N=1)$ & Not available $(N=1)$ \\
\hline & & & & $\begin{array}{l}\text { MTZ + MAra-C }(N=3) \\
\text { FLAG }(N=1) \\
\text { Allogeneic HSCT }(N=1)\end{array}$ & Not available $(N=1)$ & \\
\hline
\end{tabular}

$A M L$ acute myeloid leukaemia; age median and range in parenthesis; remission duration time from last remission in relapsed patients, median and range in parenthesis; FLT3 ITD FLT3 gene internal tandem duplication; $M$ male; $F$ female; $N$ number of patients; $3+73$ days of daunorubicin $\left(50 \mathrm{mg} / \mathrm{m}^{2}\right)+7$ days of Ara-C $\left(100 \mathrm{mg} / \mathrm{m}^{2}\right)$; HDAra-C $3 \mathrm{~g} / \mathrm{m}^{2}$ every $12 \mathrm{~h}$ for four doses; ICE 5 days of idarubicin $\left(6 \mathrm{mg} / \mathrm{m}^{2}\right), 5 \mathrm{days}$ of Ara-C $(600 \mathrm{mg} /$ $\left.\mathrm{m}^{2}\right), 3$ days of etoposide $\left(150 \mathrm{mg} / \mathrm{m}^{2}\right) ; M T Z+M A r a-C 3$ days of mitoxantrone $\left(12 \mathrm{mg} / \mathrm{m}^{2}\right)+4$ days of Ara-C $\left(1,000 \mathrm{mg} / \mathrm{m}^{2}\right) ; F L A G 5 \mathrm{days}$ of fludarabine $\left(30 \mathrm{mg} / \mathrm{m}^{2}\right)+5$ days of Ara-C $\left(2,000 \mathrm{mg} / \mathrm{m}^{2}\right) ; H S C T$ haematopoietic stem cell transplantation with myeloablative conditioning regimens 


\section{Results}

Patients Twenty-one patients (10 men, 11 women) with de novo $(N=20)$ and secondary $(N=1$, transformation from essential thrombocythaemia with $J A K 2 \mathrm{~V} 617 \mathrm{~F}$ mutation) AML, at a median age of 45 (22-62)years, were treated (Table 1). They had received a median of three (2-5) prior regimens. There were 4 primary refractory and 17 relapsed cases. For relapsed patients, three cases had relapsed from a previous myeloablative HSCT. The remission duration prior to clofarabine treatment was short at a median of 5 (2-12)months. Cytogenetic analyses were performed in 20 patients. Adverse karyotypes were identified in six patients (29\%). FLT3 gene internal tandem duplication (FLT3ITD) was detected in two patients $(10 \%)$.

Adverse effects The treatment was generally well tolerated. Common adverse effects included nausea and vomiting (grade $1 / 2, N=9,43 \%$; grade $3, N=2,10 \%$ ), rashes (grade $1 / 2, N=6,29 \%)$ and transient elevation of liver transaminases (grade $1 / 2, N=12,57 \%$; grade $3 / 4, N=2,10 \%$ ). Haematological toxicity was considerable, with all patients developing grade 4 myelosuppression. Neutropenic fever occurred in all patients, with bacterial infections documented in eight cases (38\%). Two patients died of Escherichia coli and Streptococcus viridans septicaemia on days 9 and 11 of treatment. Therefore, only 19 patients could be evaluated for response.

Complete remissions Nine patients (7 men, 2 women; median age, 50; 22-62 years), having received a median of 3 (2-4) prior regimens, achieved CR (Table 2). These included two cases with unfavourable karyotypes $(\mathrm{t}(3 ; 3)$ (q21;q26), monosomy 7). All patients had previously received Ara-C, with nine cases having standard induction at a median cumulative dose of $1.45(0.7-16.2) \mathrm{g} / \mathrm{m}^{2}$, and three cases having consolidation at a median cumulative dose of $36(36-48) \mathrm{g} / \mathrm{m}^{2}$. Interestingly, for the clofarabine/ Ara-C regimen, all patients achieving remission had received Ara-C at $2 \mathrm{~g} / \mathrm{m}^{2} /$ day, whereas none of the patients receiving Ara-C at $1 \mathrm{~g} / \mathrm{m}^{2} /$ day went into remission. Postremission, five patients elected not to receive consolidation and were still in CR at a median follow-up of $2(1-4)$ months. Three patients underwent allogeneic HSCT, one of whom had one course of clofarabine + Ara-C as consolidation pre-transplantation. Two patients were still in remission; one patient died of post-transplantation lymphoproliferative disease 4 months afterwards while still in remission. One patient received two courses of high-dose Ara-C consolidation, but relapsed 5 months later.
Table 2 Outcome of 19 AML patients receiving clofarabine and cytosine arabinoside

\begin{tabular}{|c|c|c|}
\hline Parameters & $\mathrm{CR}$ & NR \\
\hline Primary refractory $(N=4)$ & 2 & 2 \\
\hline Male & 2 & 0 \\
\hline Female & 0 & 2 \\
\hline \multicolumn{3}{|l|}{ Age } \\
\hline$\leq 50$ years & 0 & 2 \\
\hline$>50$ years & 2 & 0 \\
\hline \multicolumn{3}{|l|}{ Prior treatment regimens } \\
\hline$\leq 2$ & 1 & 0 \\
\hline$>2$ & 1 & 2 \\
\hline \multicolumn{3}{|l|}{ Cytogenetic features } \\
\hline Adverse & 0 & 2 \\
\hline Others & 2 & 0 \\
\hline \multicolumn{3}{|c|}{ Dose of cytosine arabinoside } \\
\hline $1 \mathrm{~g} / \mathrm{m}^{2}$ & 0 & 1 \\
\hline $2 \mathrm{~g} / \mathrm{m}^{2}$ & 2 & 1 \\
\hline First relapse $(N=11)$ & 5 & 6 \\
\hline Male & 3 & 1 \\
\hline Female & 2 & 5 \\
\hline \multicolumn{3}{|l|}{ Age } \\
\hline$\leq 50$ years & 4 & 4 \\
\hline$>50$ years & 1 & 2 \\
\hline \multicolumn{3}{|l|}{ Time from relapse } \\
\hline$\leq 6$ months & 2 & 5 \\
\hline$>6$ months & 3 & 1 \\
\hline \multicolumn{3}{|l|}{ Prior treatment regimens } \\
\hline$\leq 2$ & 1 & 3 \\
\hline$>2$ & 4 & 3 \\
\hline \multicolumn{3}{|l|}{ Cytogenetic features } \\
\hline Adverse & 2 & 1 \\
\hline Others & 3 & 5 \\
\hline \multicolumn{3}{|c|}{ Dose of cytosine arabinoside } \\
\hline $1 \mathrm{~g} / \mathrm{m}^{2}$ & 0 & 3 \\
\hline $2 \mathrm{~g} / \mathrm{m}^{2}$ & 5 & 3 \\
\hline Second relapse $(N=4)$ & 2 & 2 \\
\hline Male & 2 & 0 \\
\hline Female & 0 & 2 \\
\hline \multicolumn{3}{|l|}{ Age } \\
\hline$\leq 50$ years & 2 & 1 \\
\hline$>50$ years & 0 & 1 \\
\hline \multicolumn{3}{|l|}{ Time from relapse } \\
\hline$\leq 6$ months & 1 & 2 \\
\hline$>6$ months & 1 & 0 \\
\hline \multicolumn{3}{|l|}{ Prior treatment regimens } \\
\hline$\leq 2$ & 1 & 0 \\
\hline$>2$ & 1 & 2 \\
\hline \multicolumn{3}{|l|}{ Cytogenetic features } \\
\hline Adverse & 0 & 1 \\
\hline Others & 1 (NA in 1$)$ & 1 \\
\hline \multicolumn{3}{|c|}{ Dose of cytosine arabinoside } \\
\hline $1 \mathrm{~g} / \mathrm{m}^{2}$ & 0 & 0 \\
\hline $2 \mathrm{~g} / \mathrm{m}^{2}$ & 2 & 2 \\
\hline
\end{tabular}

$N A$ not available 
Non-remissions Ten patients did not achieve CR. Five patients died subsequently from refractory leukaemia, while five other patients were alive with the disease.

Prognostic indicators For the whole group, CR was unrelated to disease status, age, number of prior therapies and cytogenetic alterations. For relapsed AML, the response to clofarabine was also not associated with the duration of prior remission. However, Ara-C at $2 \mathrm{~g} / \mathrm{m}^{2} /$ day was associated with an apparent better outcome than Ara-C at $1 \mathrm{~g} / \mathrm{m}^{2} /$ day $\left(\mathrm{CR}, 9 / 15\right.$ versus $\left.0 / 4, P=0.03, \chi^{2}\right)$, although the number of cases analysed was small.

\section{Discussion}

The effectiveness of clofarabine alone or in combination with other chemotherapeutic drugs has been shown in induction treatment for adult AML, especially in elderly patients [6-8]. Besides induction therapy, phase 1 and phase 2 clinical trials had examined the efficacy of clofarabine alone [9], or combined with Ara-C and/or idarubicin, in relapsed or refractory AML $[10,11]$. In a phase 2 study, treatment of refractory and relapsed AML with clofarabine alone resulted in a CR rate of $41.9 \%$ [9]. Another phase $1 / 2$ study of clofarabine $\left(40 \mathrm{mg} / \mathrm{m}^{2} /\right.$ day $\left.\times 5\right)$ plus Ara-C $\left(1 \mathrm{~g} / \mathrm{m}^{2} /\right.$ day $\left.\times 5\right)$ in relapsed and refractory AML showed an overall response (including $\mathrm{CR}$ without platelet recovery, CRp) rate of $40 \%$ [10]. These results indicated that clofarabine had significant activity in newly diagnosed and refractory or relapsed AML. On the other hand, a recent study by the Southwest Oncology Group in patients with refractory or relapsed acute lymphoblastic leukaemia showed that clofarabine $\left(40 \mathrm{mg} / \mathrm{m}^{2} /\right.$ day $\left.\times 5\right)$ and Ara-C $\left(1 \mathrm{~g} / \mathrm{m}^{2} /\right.$ day $\left.\times 5\right)$ resulted in a CR rate of merely $17 \%$ [13]. Hence, the usefulness of clofarabine and Ara-C appears to be maximal in AML.

Our study showed a high efficacy of clofarabine plus high-dose Ara-C in refractory or relapsed AML. All our cases were heavily pre-treated, many with unfavourable karyotypes. Other traditional salvage regimens were generally regarded to be ineffective for these patients, and without innovative regimens, most cases were candidates for palliative treatment only. On an intentionto-treat basis, CR was achieved in a remarkable $43 \%$ of patients. Interestingly, Ara-C at $2 \mathrm{~g} / \mathrm{m}^{2} /$ day appeared to result in better outcome than $1 \mathrm{~g} / \mathrm{m}^{2} /$ day. The importance of Ara-C in combination with clofarabine was shown in another phase 1 study of refractory or relapsed AML, where clofarabine $\left(15-30 \mathrm{mg} / \mathrm{m}^{2} /\right.$ day $\left.\times 5\right)$ plus idarubicin $\left(12 \mathrm{mg} / \mathrm{m}^{2} /\right.$ day $\left.\times 3\right)$ resulted in a CR $+\mathrm{CRp}$ rate of $22 \%$, whereas the addition of Ara-C $\left(1 \mathrm{~g} / \mathrm{m}^{2} /\right.$ day $\left.\times 5\right)$ improved the CR rate to $48 \%$ [11]. Notably, all of our patients were previously refractory to or had relapsed from regimens containing Ara-C at standard to high doses. Moreover, of four cases where FLAG had failed (Table 1), there was one $\mathrm{CR}$ to clofarabine/Ara-C. Hence, clofarabine/ Ara-C appeared to be still effective in cases otherwise considered to be refractory to Ara-C. However, further studies may be required to define the optimal dose of Ara-C to be used in combination with clofarabine and the actual margin of clinical benefit derived from the clofarabine/Ara-C combination as compared with each of the drugs alone.

The main toxicity of our regimen was myelosuppression. Two patients died of septicaemia. Therefore, routine use of myeloid growth factors and aggressive treatment of any signs of sepsis are needed.

In conclusion, clofarabine plus high-dose Ara-C is a feasible, safe and efficacious therapy for refractory or relapsed adult AML. Future studies are needed to examine the effectiveness of this regimen in induction therapy, and whether higher doses of Ara-C can be administered safely and more efficaciously.

Conflict of interest The authors have no conflict of interests to declare.

Open Access This article is distributed under the terms of the Creative Commons Attribution Noncommercial License which permits any noncommercial use, distribution, and reproduction in any medium, provided the original author(s) and source are credited.

\section{References}

1. Craddock C, Tauro S, Moss P, Grimwade D (2005) Biology and management of relapsed acute myeloid leukaemia. Br J Haematol 129:18-34

2. Gandhi V, Estey E, Keating MJ, Plunkett W (1993) Fludarabine potentiates metabolism of cytarabine in patients with acute myelogenous leukemia during therapy. J Clin Oncol 11:116-124

3. Jackson G, Taylor P, Smith GM, Marcus R, Smith A, Chu P, Littlewood TJ, Duncombe A, Hutchinson M, Mehta AB, Johnson SA, Carey P, MacKie MJ, Ganly PS, Turner GE, Deane M, Schey S, Brookes J, Tollerfield SM, Wilson MP (2001) A multicentre, open, non-comparative phase II study of a combination of fludarabine phosphate, cytarabine and granulocyte colonystimulating factor in relapsed and refractory acute myeloid leukaemia and de novo refractory anaemia with excess of blasts in transformation. Br J Haematol 112:127-137

4. Martin MG, Augustin KM, Uy GL, Welch JS, Hladnik L, Goyal S, Tiwari D, Monahan RS, Reichley RM, Cashen AF, StockerlGoldstein K, Westervelt P, Abboud CN, Dipersio JF, Vij R (2009) Salvage therapy for acute myeloid leukemia with fludarabine, cytarabine, and idarubicin with or without gemtuzumab ozogamicin and with concurrent or sequential G-CSF. Am J Hematol 84:733-737 
5. Sampat K, Kantarjian H, Borthakur G (2009) Clofarabine: emerging role in leukemias. Expert Opin Investig Drugs 18:1559-1564

6. Faderl S, Ravandi F, Huang X, Garcia-Manero G, Ferrajoli A, Estrov Z, Borthakur G, Verstovsek S, Thomas DA, Kwari M, Kantarjian HM (2008) A randomized study of clofarabine versus clofarabine plus low-dose cytarabine as front-line therapy for patients aged 60 years and older with acute myeloid leukemia and high-risk myelodysplastic syndrome. Blood 112:1638-1645

7. Kantarjian HM, Erba HP, Claxton D, Arellano M, Lyons RM, Kovascovics T, Gabrilove J, Craig M, Douer D, Maris M, Petersdorf S, Shami PJ, Yeager AM, Eckert S, Abichandani R, Faderl S (2010) Phase II study of clofarabine monotherapy in previously untreated older adults with acute myeloid leukemia and unfavorable prognostic factors. J Clin Oncol 28:549-555

8. Burnett AK, Russell NH, Kell J, Dennis M, Milligan D, Paolini S, Yin J, Culligan D, Johnston P, Murphy J, McMullin MF, Hunter A, Das-Gupta E, Clark R, Carr R, Hills RK (2010) European development of clofarabine as treatment for older patients with acute myeloid leukemia considered unsuitable for intensive chemotherapy. J Clin Oncol 28:2389-2395

9. Kantarjian H, Gandhi V, Cortes J, Verstovsek S, Du M, GarciaManero G, Giles F, Faderl S, O'Brien S, Jeha S, Davis J, Shaked Z, Craig A, Keating M, Plunkett W, Freireich EJ (2003) Phase 2 clinical and pharmacologic study of clofarabine in patients with refractory or relapsed acute leukemia. Blood 102:2379-2386

10. Faderl S, Gandhi V, O'Brien S, Bonate P, Cortes J, Estey E, Beran M, Wierda W, Garcia-Manero G, Ferrajoli A, Estrov Z, Giles FJ, Du M, Kwari M, Keating M, Plunkett W, Kantarjian H (2005) Results of a phase 1-2 study of clofarabine in combination with cytarabine (ara-C) in relapsed and refractory acute leukemias. Blood 105:940-947

11. Faderl S, Ferrajoli A, Wierda W, Huang X, Verstovsek S, Ravandi F, Estrov Z, Borthakur G, Kwari M, Kantarjian HM (2008) Clofarabine combinations as acute myeloid leukemia salvage therapy. Cancer 113:2090-2096

12. Grimwade D, Hills RK, Moorman AV, Walker H, Chatters S, Goldstone AH, Wheatley K, Harrison CJ, Burnett AK (2010) Refinement of cytogenetic classification in acute myeloid leukemia: determination of prognostic significance of rare recurring chromosomal abnormalities among 5876 younger adult patients treated in the United Kingdom Medical Research Council trials. Blood 116:354-365

13. Advani AS, Gundacker HM, Sala-Torra O, Radich JP, Lai R, Sloval ML, Lancet JE, Coutre SE, Stuart RK, Mims MP, Stiff PJ, Appelbaum FR (2010) Southwest Oncology Group Study S0530: a phase 2 trial of clofarabine and cytarabine for relapsed or refractory acute lymphocytic leukaemia. Br J Haematol 151:430-434 